\title{
Rice Diversity Panel Mapping for Identifying Genetics Behind Leaf Vein Density Trait in Rice (Oryza sativa L.)
}

\author{
Zaniab Al-Shugeairy \\ Field Crop Department, College of Agriculture, University of Baghdad, Baghdad, Iraq
}

Email address:

zainab_fa2000@yahoo.com

To cite this article:

Zaniab Al-Shugeairy. Rice Diversity Panel Mapping for Identifying Genetics Behind Leaf Vein Density Trait in Rice (Oryza sativa L.). International Journal of Applied Agricultural Sciences. Vol. 2, No. 4, 2016, pp. 49-55. doi: 10.11648/j.ijaas.20160204.12

Received: May 14, 2016; Accepted: June 13, 2016; Published: June 20, 2016

\begin{abstract}
A screen of rice genotypes was carried out on a total of 327 genotypes of the rice diversity panel for leaf vein density. Identifying locations of genes that impart to leaf vein density in a quantitative way should capable the using of these genes in plant breeding and accelerate producing $\mathrm{C} 4$ rice plant. Finding of genotypes of rice that have less distances between veins is still the challenge of the plant breeders. Screen was shown significant variations in leaf vein density. Quantitative trait loci (QTLs) for the leaf vein density trait were identified by using Efficient Mixed Model Analysis (EMMA). QTLs were considered reportable if they had $P$ values (below 0.0001). The most significant Single nucleotide polymorphisms (SNP) associations (EMMA 1.3, EMMA 1.8 and EMMA 10.1) were in each of the rice chromosomes 1 and 10 respectively. All genes positioned $200 \mathrm{~kb}$ around associations were selected. The candidacy of the most promising were NADP-dependent malic enzyme, chloroplast precursor (LOC_Os01g09320; ras-related protein, putative, expressed (LOC_Os01g51700); 60S acidic ribosomal protein (LOC_Os01g09510); Auxin-responsive Aux/IAA gene family member (LOC_Os01g09450; myb-related transcription activator, putative, expressed (LOC_Os01g09280); glycine-rich protein (LOC_Os01g09246); phosphofructokinase (LOC_Os01g09570); oxidoreductase, short chain dehydrogenase/reductase family (SDR) LOC_Os10g31780), which have been expressed in leaf tissue and requisite to be investigated further.
\end{abstract}

Keywords: Rice Diversity Panel, Rice, Leaf Vein Density, Mapping

\section{Introduction}

To meet the ever growing world population, it is necessary to increase yield that can only be done by increasing the efficiency with which photosynthesis uses solar energy $[1,2]$. Plants are differing in canopy photosynthesis that leads to differences by about $50 \%$ between plants in the radiation use efficiencies [3, 4]. C4 crops, grown in hot and dry environments, have higher yields, reduced water loss and increased nitrogen use efficiency compared to $\mathrm{C} 3$ crops such as rice. Plants use three photosynthetic pathways [5]. Plants that are called $\mathrm{C} 3$ produce a three-carbon compound by using photosynthetic pathway in which $\mathrm{CO} 2$ is fixed by Ribulose Bisphosphate Carboxylase/Oxygenase (RuBisCO) in the Calvin-Benson cycle. Whereas species, that evolved from $\mathrm{C} 3$ plants, use the $\mathrm{C} 4$ and Crassulacean Acid Metabolism (CAM) pathways, and in both cases, a four-carbon compound is initially formed from fixation of $\mathrm{HCO} 3$. It is suggested that C3 is the ancestral pathway. Thus, C4 and CAM are forms diverged from $\mathrm{C} 3$ plants in recent times. The majority of $\mathrm{C} 4$ plants, and certainly all known $\mathrm{C} 4$ grasses, compartmentalize photosynthetic reactions between two morphologically distinct cell types that are located in circles around veins [6]. There are enlarged bundle sheath (BS) cells around the veins that are surrounded by mesophyll (M) cells that called Kranz anatomy. This structure produces a consistent interveinal distance of four cells (vein-BS-M-M-BS-vein). Each of BS and $\mathrm{M}$ cells shared metabolic reactions such that $\mathrm{C} 4$ acids are generated in $\mathrm{M}$ cells and then diffuse to the BS where the Calvin-Benson cycle operates. Restricting the expression of a few numbers of genes to either the BS or M cells achieves this separation of metabolism. [7] reported that Carbonic anhydrase (CA), phosphoenolpyruvate carboxylase (PEPC), NADP-malate dehydrogenease (MDH), pyruvate orthophosphate dikinase (PPDK) and the proteins involved in their post-translational regulation accumulate in the $\mathrm{M}$ cells, while NADP-malic enzyme (ME) and RuBisCO are restricted to the BS. All of these enzymes encoded by genes that are present in $\mathrm{C} 3$ plants, but the levels of expression are much lower than in $\mathrm{C} 4$ species. According to the polyphyletic evolution of the $\mathrm{C} 4$ pathway, the transition from C3 to C4 seems to be relatively simple. the most obvious differences between leaf morphology in $\mathrm{C} 3$ and $\mathrm{C} 4$ plants is 
leaf venation pattern indicating that veins play an important role in the differentiation of $\mathrm{C} 4$ leaf anatomy. Vein density measured in a range of $\mathrm{C} 3$ and $\mathrm{C} 4$ species demonstrated that veins are consistently more closely spaced in $\mathrm{C} 4$ species [8]. in addition, quantitative measurements of BS-to-M cell ratios in $\mathrm{C} 3$ and $\mathrm{C} 4$ leaves showed that in $\mathrm{C} 4$ plants the ratio approaches $1: 1[9,10,11]$. This ratio equates to veins (V) being separated by only four photosynthetic cells in $\mathrm{C} 4$ leaves as opposed to up to 20 cells in $\mathrm{C} 3$ leaves. As such, the repeating V-BS-M-M-BS-V unit of Kranz anatomy is produced. One remarkable exception to this repeating model is found in Arundinella hirta, a C4 grass that exhibits an atypical anatomy where wreaths of so-called distinctive cells are found between V-BS-M-M-BS-V units [12, 13]. The distinctive cells carry out the same function as BS cells but are not themselves associated with veins $[14,15,16]$. Notably, if the number of BS and distinctive cells is combined, the 1:1 ratio is also observed in Arundinella hirta (17) reported that a comparison of vascular development in C3 and C4 Flaveria species showed that both the major and minor veins were commenced at comparable stages in development but that a higher number of minor veins were commenced in the $\mathrm{C} 4$ species. An acquisition of a mechanism to induce procambium at more regular intervals across the leaf may be the first step in the evolution of Kranz anatomy. The role of auxin in vascular development is recognized, it is probably that such a mechanism was adapted from existing auxin pathways. A study that compared anatomical and biochemical differences between 16 Flaveria species that included C3, C3-C4 intermediate, C4-like, and $\mathrm{C} 4$ types gave more evidence for the suggestion that changed vein patterning was an early modification in the evolution of $\mathrm{C} 4$. To find accessions of rice with less interveinal distance is the challenge for plant breeder. To determine the extent to which rice leaf morphology can vary, it is important to screen rice genome wide association for leaf morphology to determine variations in interveinal distance.

\section{Material and Methods}

The layout of this experiment was randomized complete block design with four replications. A subset of 327 accessions was utilised for this study. Of those examined, 279 belonged to the rice subpopulations aromatic 9, aus 53, indica 57 , temperate japonica 75 or tropical japonica 85 . The other 48 accessions were grouped as admixtures between subpopulations. This experiment used box (length 450, width 90 and depth $40 \mathrm{~cm}$ ) filled with loam top soil from Rolawn Ltd (UK). A plastic sheet $(450 \times 90 \mathrm{~cm})$ was placed on the top of the soil (soil surface). This plastic sheet with 1308 perforations ( $2 \mathrm{~cm}$ diameter) for sowing rice plants at depth $1.5 \mathrm{~cm}$ using 5 x $5 \mathrm{~cm}$ spacing was made. On 2013, 327 rice diversity panel accessions were sown. for 12 hours a day, supplementary light of $150 \mu \mathrm{mol} \mathrm{m} \mathrm{s}$ Photosynthetically active radiation (PAR) was supplied within temperature range from $28-30^{\circ} \mathrm{C}$ and watered with Yoshida's full strength nutrient solution [18]. Vein counts were made off-site at green house - University of Aberdeen from images snapped of freshly collected leaves. Veins images in the second completely expanded newly harvested youngest leaf at 8 weeks after sowing were captured for screening the 327 rice diversity panel by a digital camera model canon (EOS 7D Mark II DSLR Camera, 20.2 MP). Veins were counted at the widest area of the leaf including the midrib or edges (Figure 1).

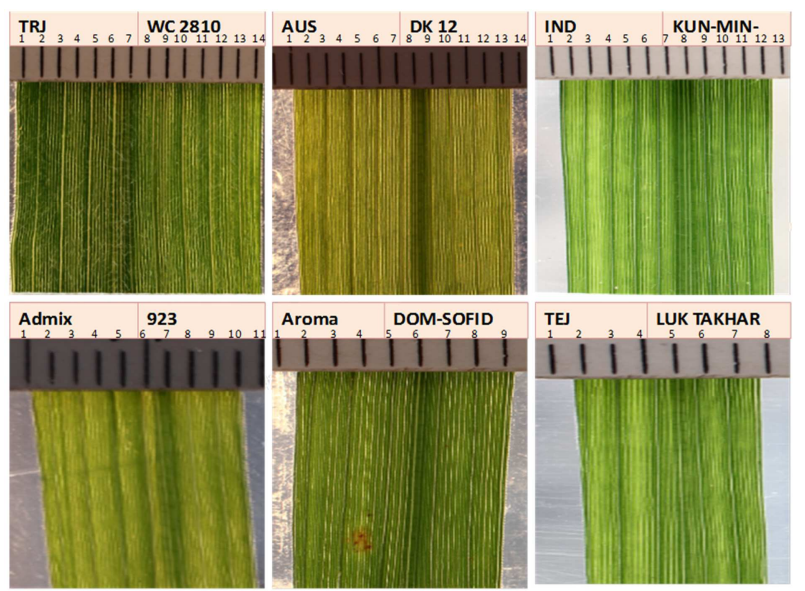

Figure 1. Images of leaf vein of different rice subpopulation (indica (IND), aus, aromatic (Aroma), tropical japonica (TRJ) and temperate japonica (TEJ)) at 8 weeks after sowing. Scale in millimetre.

Genotyping of the Rice Diversity Panel has been done at Cornell University, New York on an Affymetrix genotyping array which includes of 44,100 SNPs distributed over the rice genome $(380 \mathrm{Mb})$ [19]. For this SNP chip, the estimation was about $1 \mathrm{SNP} / 10 \mathrm{~kb}$ coverage [20]. The association mapping analysis was done by Dr. Alexander Douglas Statistician and Bioinformatician (University of Aberdeen). An Efficient Mixed Model Analysis (EMMA) accounting for population structure was performed on all the genotypes according to methods reported by [21] that modified from [22] who developed a novel mixed-model method to simultaneously take into account for many levels of relatedness identified by random genetic markers. In addition, this analysis with EMMA plus separate sub-populations is the same to the statistical method adopted by [19] in the first publication mapping traits using this SNP data on this population. The result presented by Dr Douglas provided were many files containing 4 pdf files (Histogram, Manhattan mixed, Manhattan naïve and QQ plot). In addition, the statistic for the minor allele frequency value that was taken from previous analysis of other data was performed, and has relation with the allele of the SNP that is of lowest frequency within the genotypes. The SNP was considered potentially not reliable, when this proportion was less than 0.05 , Furthermore, analysis of the separate subspecies was done; the aromatic and admixtures were removed from the data set prior to association mapping analyses as there were insufficient numbers of those within these subspecies. As well as, the four subspecies of association populations were analysed for association mapping. It's important to mention that the literature proposes that there is no uniform threshold $P$ value that can be considered in rice diversity panel [19]. In current study, QTLs were considered reportable if they had multiple close (within $200 \mathrm{~kb}$ ) SNPs with low $P$ values (below 0.0001) and where at least some of these SNPs did not have minor allele frequencies below 5\%. Using the 
method of [19], genes positioned approximately $200 \mathrm{~kb}$ around associations (excluding transposons) were considered positional candidates (assuming linkage disequilibrium of $200 \mathrm{~kb}$ ). Consequently, lists of genes within this location were collected via the rice Pseudomolecule version 6 from the rice genome annotation scheme. So in order to collect more data about candidate genes, the expression pattern of each was evaluated bioinformatically via the database of rice expression profile (RiceXPro) that can be found at http://ricexpro.dna.affrc.go.jp/ after converting Rice Genome Annotation Project (RGAP) names to International Rice Genome Sequencing Project (IRGSP) titles at http://rapdb.dna.affrc.go.jp/tools/converter/run. Furthermore, the candidate genes with clear expression in leaf tissue were considered further in the literature to decide whether they are related to cell growth or leaf vein development in other studies which would nominate them excellent candidate genes.

\section{Statistical and bioinformatic analysis}

All the data were analysed using Minitab version 15. Twoway ANOVA with factors genotype and block was applied. The data were corrected for the block effect and also for normality by using base $\log _{10}$. Using EMMA, the association mapping analysis was made. The reliability of Trait-marker associations was with $P$ values below 0.0001 . The significant SNPs were tested for minor allele frequencies, with values above 0.05 considered to be reliable. All genes located with $200 \mathrm{~kb}$ of the QTL identified were selected as positional candidates. To distinguish between genes and likely psuedogenes, all the candidate genes have been tested for full-length cDNA (fl, cDNA) and expressed sequence tag (EST) [23]. In order to test gene expression in plant leaves, the database of RiceXPro at http://ricexpro.dna.affrc.go.jp/ was used [24]. Furthermore, the candidate genes with significant expression were examined for whether they are linked to leaf vein density or even to cell development through literature studying to decrease the number of candidate genes.

\section{Results and Discussion}

Leaf vein density was assessed at eight weeks after sowing. The output of One-way ANOVA showed that there were high significant differences in leaf vein density between the genotypes $\left(\mathrm{F}=2.71, P<0.001, \mathrm{R}^{2}=30.03\right)$. The genotypes NOVA, BJ 1, WC 4419, HATSUNISHIKI, LD 24, GEUMOBYEO, LEUANG, HAWN, SL 22-613 and WIR 3039 had the highest value for leaf vein density while the genotypes Pirinae 69, Lomello, 9524, Halwa Gose red, SUFAID, GOTAK GATIK, Italica Carolina, LACROSSE, WC 6 and VICTORIA F. A had the lowest value (Figure 2). Figure 3 presents the cumulative distributions of $P$ values in a rice diversity panel scan for leaf vein density again showing the value of the mixed model in controlling false positive associations. Association analysis of the leaf vein density is presented graphically in Figure 3. Use of EMMA revealed that three SNP are significantly associated with leaf vein density using a threshold value from the association analysis of under $0.0001\left(-\log _{10} P=4\right)$ (Figure 4, Table 1). The most significant SNP association ware EMMA 1.3, EMMA 1.8 and EMMA 10.1 with minor allele frequency are $0.40,0.37$ and 0.46 respectively which indicates that this association is reliable. From association analysis for individual rice groups aus, indica, tropical japonica and temperate japonica with leaf vein density were detected (Figure 5). In the present study only those SNPs detected in the mixed model have been taken forward for listing candidate genes.

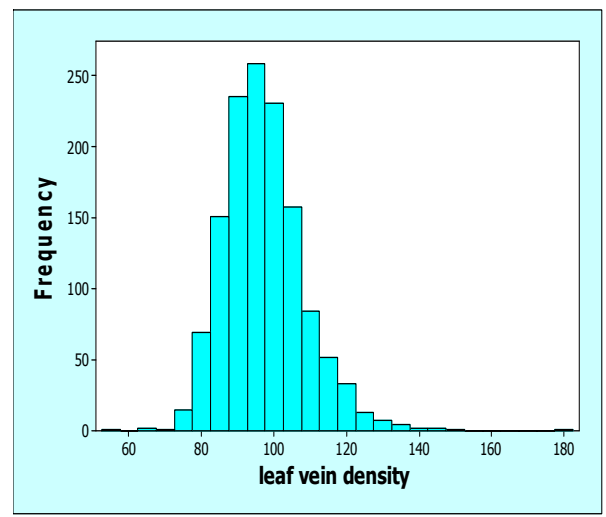

Figure 2. Histogram of leaf vein density for different rice genotypes at 8 weeks after sowing.

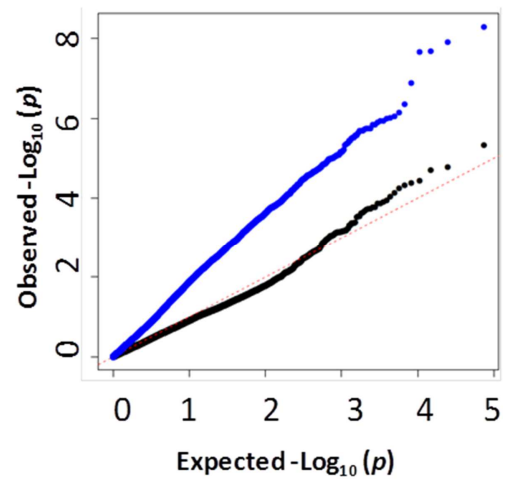

Figure 3. Cumulative distributions of $P$-values in rice diversity panel scan for leaf vein density. The upper dotted line is the naïve data plot, lower dotted line is the data corrected for population structure using efficient mixed-model association (EMMA). The faint dotted line is a $y=x$ plot.

Table 1. seventy six associated SNPs with rice diversity panel significance for leaf vein density.

\begin{tabular}{lllll}
\hline $\begin{array}{l}\text { Association } \\
\text { name }\end{array}$ & Chromosome & SNP id & Position (bp) & -logP \\
\hline EMMA1.1 & 1 & id1003850 & 4649725 & 2.741437 \\
EMMA1.2 & 1 & id1003922 & 4754473 & 4.431066 \\
EMMA1.3 & 1 & id1003932 & 4816430 & 4.76643 \\
EMMA1.4 & 1 & id1003946 & 4824928 & 3.125417 \\
EMMA1.5 & 1 & id1003966 & 4869563 & 3.768984 \\
EMMA1.6 & 1 & id1003969 & 4870786 & 4.027962 \\
EMMA1.7 & 1 & id1015694 & 26923741 & 3.216116 \\
EMMA1.8 & 1 & id1017799 & 29870072 & 5.316268 \\
EMMA1.4 & 1 & id1017800 & 29870105 & 3.931617 \\
EMMA1.10 & 1 & id1018186 & 30259251 & 3.862305 \\
EMMA1.11 & 1 & id1018208 & 30277466 & 3.852993 \\
EMMA1.12 & 1 & id1018264 & 30372127 & 2.983439 \\
EMMA1.13 & 1 & id1019252 & 31733901 & 3.137514 \\
EMMA1.14 & 1 & id1019318 & 31810076 & 3.112504 \\
EMMA1.15 & 1 & id1019442 & 31975536 & 4.703504 \\
EMMA1.16 & 1 & id1019599 & 32098049 & 2.88368 \\
EMMA1.17 & 1 & id1019921 & 32417755 & 4.245419 \\
EMMA1.18 & 1 & id1019965 & 32448978 & 3.776631 \\
EMMA1.19 & 1 & id1020064 & 32537533 & 3.548692 \\
EMMA1.20 & 1 & id1020172 & 32657373 & 3.383683 \\
\hline
\end{tabular}




\begin{tabular}{lllll}
\hline $\begin{array}{l}\text { Association } \\
\text { name }\end{array}$ & Chromosome & SNP id & Position (bp) & $-\log \boldsymbol{P}$ \\
\hline EMMA2.1 & 2 & id2010961 & 25248042 & 2.961937 \\
EMMA3.1 & 3 & id3002904 & 4870549 & 3.092584 \\
EMMA3.2 & 3 & id3002906 & 4870903 & 3.141756 \\
EMMA3.3 & 3 & id3002970 & 4984657 & 3.039798 \\
EMMA3.4 & 3 & id3011375 & 27044188 & 3.161961 \\
EMMA3.5 & 3 & id3011400 & 27088843 & 3.140736 \\
EMMA3.6 & 3 & id3011406 & 27094275 & 3.143558 \\
EMMA3.7 & 3 & id3011485 & 27274022 & 3.312589 \\
EMMA3.8 & 3 & id3011493 & 27278957 & 3.371414 \\
EMMA3.9 & 3 & id3011506 & 27304002 & 3.361587 \\
EMMA3.10 & 3 & id3011582 & 27382750 & 2.872733 \\
EMMA3.11 & 3 & id3011726 & 27463661 & 3.071912 \\
EMMA3.12 & 3 & id3016016 & 33093386 & 2.777638 \\
EMMA3.13 & 3 & id3018359 & 36129563 & 3.148368 \\
EMMA41 & 4 & id4001786 & 4317452 & 2.899073 \\
EMMA4.3 & 4 & id4006437 & 20381599 & 2.776798 \\
EMMA6.1 & 6 & id6004216 & 6599402 & 3.055338 \\
EMMA6.2 & 6 & id6011598 & 22312304 & 3.17969 \\
EMMA6.3 & 6 & id6011606 & 22316719 & 3.176603 \\
EMMA6.4 & 6 & id6014187 & 26188962 & 3.016867 \\
EMMA6.5 & 6 & id6016050 & 27844031 & 3.363608 \\
EMMA6.6 & 6 & id6016215 & 28383507 & 2.965974 \\
EMMA7.1 & 7 & id7004157 & 23422997 & 3.153137 \\
EMMA8.1 & 8 & id8004945 & 18672697 & 3.680596 \\
EMMA9.1 & 9 & wd9001498 & 10122677 & 2.871118 \\
EMMA10.1 & 10 & id10004603 & 16614044 & 4.379868 \\
EMMA10.2 & 10 & id10004606 & 16615168 & 4.32307 \\
EMMA10.3 & 10 & id10004614 & 16619029 & 3.736666 \\
\hline
\end{tabular}

*EMMA1.1 refers to the method by which the rice diversity panel was analysed, chromosome number, the SNP order within each chromosome. The highly significant associations are in bold.

Table 1. Continued seventy six associated SNPs with rice diversity panel significance for leaf vein density

\begin{tabular}{lllll}
\hline $\begin{array}{l}\text { Association } \\
\text { name }\end{array}$ & Chromosome & SNP id & Position (bp) & -logP \\
\hline EMMA10.4 & 10 & id10007116 & 22476823 & 3.121138 \\
EMMA10.5 & 10 & id10007134 & 22494504 & 2.938758 \\
EMMA10.6 & 10 & id10007137 & 22497992 & 3.722401 \\
EMMA10.7 & 10 & id10007143 & 22502368 & 3.900588 \\
EMMA10.8 & 10 & id10007152 & 22503803 & 3.711377 \\
EMMA10.9 & 10 & id10007153 & 22504612 & 3.012452 \\
EMMA10.10 & 10 & id10007165 & 22576427 & 3.524363 \\
EMMA10.11 & 10 & id10007166 & 22576547 & 3.625706 \\
EMMA10.12 & 10 & id10007167 & 22576599 & 3.313808 \\
EMMA10.13 & 10 & id10007176 & 22611907 & 4.127244 \\
EMMA10.14 & 10 & ud10001291 & 22648621 & 2.859625 \\
EMMA11.1 & 11 & dd11000503 & 21975605 & 3.617917 \\
EMMA11.2 & 11 & dd11000982 & 22148499 & 3.050962 \\
EMMA11.3 & 11 & dd11000986 & 22148852 & 2.713268 \\
EMMA11.4 & 11 & dd11000988 & 22148992 & 2.702486 \\
EMMA11.5 & 11 & dd11000989 & 22149066 & 3.07144 \\
EMMA11.6 & 11 & dd11000992 & 22149249 & 2.714034 \\
EMMA11.7 & 11 & dd11000994 & 22149315 & 3.178163 \\
EMMA11.8 & 11 & id11008642 & 22149608 & 2.908412 \\
EMMA11.9 & 11 & id11008863 & 22558101 & 3.241729 \\
EMMA11.10 & 11 & id1008875 & 22610675 & 2.956577 \\
EMMA11.11 & 11 & id11008887 & 22616701 & 2.831769 \\
EMMA11.12 & 11 & id11008894 & 22648493 & 3.159423 \\
EMMA12.1 & 12 & id12007710 & 22740633 & 2.74965 \\
EMMA12.2 & 12 & id12009451 & 25871148 & 2.956367 \\
EMMA12.3 & 12 & id12009470 & 25890219 & 3.045969 \\
EMMA12.4 & 12 & id12009931 & 27171774 & 3.533409 \\
\hline
\end{tabular}

*EMMA1.1 refers to the method by which the rice diversity panel was analysed, chromosome number, the SNP order within each chromosome. The highly significant associations are in bold.
Assessing of vein density of leaf in 327 rice accessions considered as a long term aim of introducing the mechanism of $\mathrm{C} 4$ into $\mathrm{C} 3$ plants. It was possible to show that there was significant variation across genotypes perhaps reflecting differences in the degree of the close relation between development of the vein and leaf width is associated to fracture proliferation in stretched material that leads to auxinlike signals in the new spaces in which new veins can be formed. Consequently, the link connecting the formation of auxin and vascular might explain the link between vein density and width of leaf [25]. In addition, the substantial variation in leaf vein density among genotypes was indentifying in current study which is confirmed by [25] who reported that there is variation in vein density, also by examining two rice mutants, they found that the trait of narrow leaf width was related to a high vein density trait but there was incomplete linkage. However more studies need to be done in order to exploit data above to set up future investigation. In addition, all genes situated $200 \mathrm{~kb}$ around associations, that include candidate gene lists detected by using the EMMA approach, were chosen (Table 1). The RiceXPro database shows that many candidate genes are expressed in leaf tissue. From these, eight stand out after seeking gene function in the literature (Table 2).
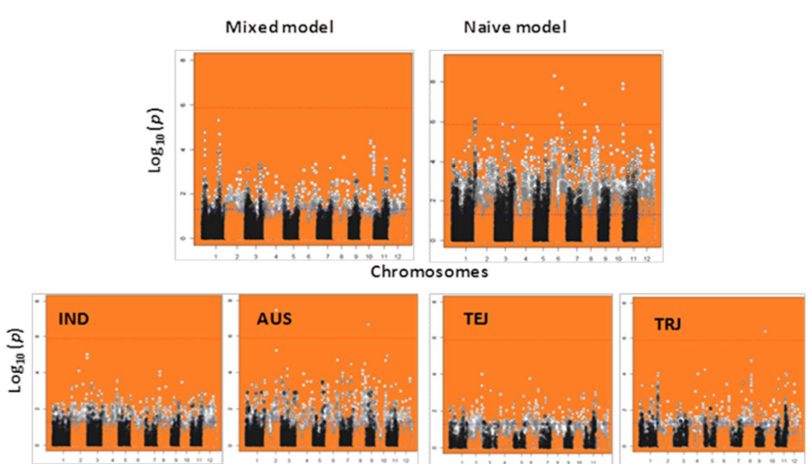

Chromosomes

Figure 4. P-values of rice diversity panel from the naïve model, mixed model, and each subpopulation (aus, indica, tropical japonica and temperate japonica) for leaf vein density at eight weeks after sowing.

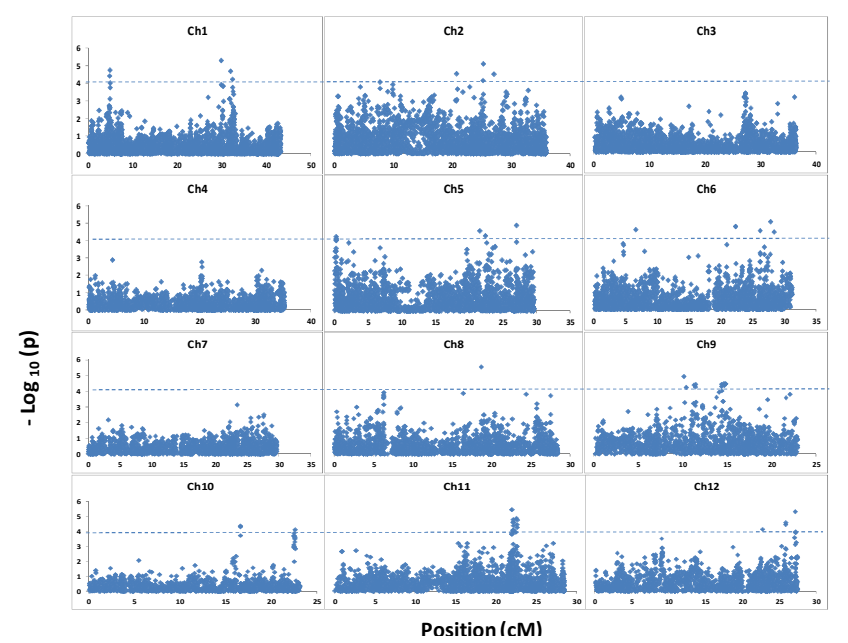

Figure 5. rice diversity panel of leaf vein density. Data corrected for population structure by efficient mixed-model association. Dashed line shows threshold at $-\log _{10}(P$-value $=4)$. 
Table 2. The most significant candidate genes, all the candidate genes were tested for expression density (Fluoresce yellow-green Cyanine dye, Cy3) using rice expresion profile database (RiceXPro). The Symbol $(\sqrt{ })$ refers to a positive expression of (Cy3) and the Symbol ( $x$ ) refers to a lack of expression in leaves.

\begin{tabular}{|c|c|c|c|c|c|}
\hline $\begin{array}{l}\text { Location from } \\
5 \text { ' end (bp) }\end{array}$ & RGAP number & $\begin{array}{l}\text { Express in leaf } \\
\text { tissue }(\mathrm{Cy} 3)\end{array}$ & $\begin{array}{l}\text { Express in all } \\
\text { plant tissue (Cy3) }\end{array}$ & fl cDNA or EST? & Rice Genome Project annotation \\
\hline 4743591 & LOC_Os01g09320 & $200-12000$ & p & fl_cDNA & $\begin{array}{l}\text { NADP-dependent malic enzyme, chloroplast } \\
\text { precursor, putative, expressed }\end{array}$ \\
\hline 29734069 & LOC Os01g51700 & $1000-4200$ & $\sqrt{ }$ & EST & ras-related protein, putative, expressed \\
\hline 4851430 & LOC_Os01g09510 & $5000-100000$ & $\sqrt{ }$ & EST & $60 \mathrm{~S}$ acidic ribosomal protein, putative, expressed \\
\hline 4815845 & LOC_Os01g09450 & $1000-10000$ & $\sqrt{ }$ & EST & $\begin{array}{l}\text { OsIAA2 - Auxin-responsive Aux/IAA gene family } \\
\text { member, expressed }\end{array}$ \\
\hline 4672400 & LOC_Os01g09246 & $100-7000$ & $\sqrt{ }$ & fl_cDNA & glycine-rich protein, putative, expressed \\
\hline 4904501 & LOC_Os01g09570 & $3000-30000$ & $\sqrt{ }$ & fl_cDNA & $\begin{array}{l}\text { 6-phosphofructokinase, putative, expressed } \\
\text { oxidoreductase, short chain }\end{array}$ \\
\hline 16592705 & LOC_Os10g31780 & $1000-150000$ & $\sqrt{ }$ & & $\begin{array}{l}\text { dehydrogenase/reductase family domain containing } \\
\text { protein, expressed }\end{array}$ \\
\hline
\end{tabular}

NADP-dependent malic enzyme, chloroplast precursor (LOC_Os01g09320). NADP-malic enzyme is belongs to the family of oxidoreductases. In addition, the systematic name of this enzyme class is (S)-malate: $\mathrm{NAD}^{+}$oxidoreductase (decarboxylating) [26, 27]. Most importantly, a study done by [28] confirmed that NADP-malic enzyme involved in C4 photosynthetic pathway in seven rice genotypes during grain filling stage. Furthermore, this gene is considered to be excellent candidate because it is linked to function in pyruvate metabolism and carbon fixation and has experssion intensity in leaf tissue of approximately $12000 \mathrm{Cy} 3$.

Ras-related protein, putative, expressed (LOC_Os01g51700). The rgp1 is a gene that encodes rasrelated GTP-binding protein. [29] reported that transgenic tobacco plants expressing rgp1, show different morphological characteristics. For example, some R1 progenies of selfpollinating plants developed abnormal leaf phenotypes, such as the abnormal branching of the main vein leading to the formation of twin or even triple leaves [29]. This may nominate this gene as a good candidate gene. The database RiceXPro reported that this gene had expression intensity in leaf tissue just about $4200 \mathrm{Cy} 3$.

$60 \mathrm{~S}$ acidic ribosomal protein (LOC_Os01g09510). The GTPase large subunit GTPase 1 (LSG1) is responsible for the steps through which the $60 \mathrm{~S}$ ribosome is been maturated. An Arabidopsis mutant dig6 exhibited multiple auxin-related phenotypes such as altered leaf veins. Furthermore, the expression of this gene was found to be high in regions where the auxin can be accumulated and have role in the development of ribosome [30]. The database RiceXPro showed that this gene had expression intensity in leaf tissue reaching nearly $100000 \mathrm{Cy} 3$.

Auxin-responsive Aux/IAA gene family member (LOC_Os01g09450). Gene expression regulates partially the acts of Auxin. Genes regulated by the Auxin can be classified into many gene families, such as the $A u x / I A A$, the $S A U R$ and the $G H 3$ family [31]. In addition, different growth and development stages of plant are mediated by auxin and are transported all through the plant [32]. The $A X R 2$ gene was cloned by [33] from Arabidopsis plant showing that it is like to $I A A 7$ gene, which is one of gene family that is responsible for making morphological responses to normal light.
RiceXPro database showed that this gene had an experssion intensity in leaf tissue of roughly $10000 \mathrm{Cy} 3$.

Myb-related transcription activator, putative, expressed (LOC_Os01g09280). MYB proteins constitute a large family of transcription factors [34]. [35] confirm the important role of the MYB family in the metabolism and development of plant. Moreover, RiceXPro database suggested this gene had expression intensity in leaf tissue that reach of about 1250 Cy3.

Glycine-rich protein (LOC_Os01g09246). Glycine-rich protein is a group of proteins that responsible for cell wall structure. This group of proteins occurs in several higher plant species and its expression in vascular tissue of rice was reported by [36]. RiceXPro database showed that this gene had expression intensity in leaf tissue that about $7000 \mathrm{Cy} 3$.

6-phosphofructokinase (LOC_Os01g09570). Isozymes of 6-phosphofructokinase are found in the cytosol and plastid compartments and this gene have role for developing leaf tissue [37]. In addition, RiceXPro database revelled that this gene had expression intensity in leaf tissue around 30000 Cy3.

Oxidoreductase, short chain dehydrogenase /reductase family (SDR) LOC_Os10g31780). This gene has very large family consists of at least 140 different enzymes. The SDR family comprise ABA2 [38, 39]. The ABA2 gene, which involved in ABA biosynthesis, encodes OST1 gene. This gene encodes a protein, which controlled by ABA is responsible for stomatal closure [40]. In addition, RiceXPro database showed that this gene had an expression intensity in leaf tissue namely about $150000 \mathrm{Cy} 3$.

Improving high yielding rice genotype is a target of rice breeders. Therefore, understanding the mechanisms affecting leaf vein density is an important matter for rice breeding. However, the mechanisms underlying leaf vein density are complicated.

\section{Conclusion}

Detecting quantitative trait loci (QTLs) which confer leaf vein density promises to speed up the aim of this experiment. In this study differences in leaf vein density between rice genotypes has been exposed and QTL identified. These data 
point out areas of the rice genome containing genes of potential value in breeding leaf vein density rice. These candidate genes are worthy further investigation.

\section{Acknowledgment}

I am thankful to Dr Adam price for guidance and help with screening of the rice diversity panel and Dr. Alexander Douglas Statisticianand Bioinformatician at University of Aberdeen for their expertise and assistance.

\section{References}

[1] Mitchell, P. and J. Sheehy. 2006. Supercharging rice photosynthesis to increase yield. New Phytologist, 171: 688693.

[2] Long S. P, X-G Zhu, S. Naidu and D. Ort. 2006. Can improvement in photosynthesis increase crop yields? Plant Cell Environ. 29: 315-330.

[3] Kiniry, J.; C. Jones; J. O’Toole; R. Blanchet; M. Cabelguenne and D. Spanel. 1989. Radiation use efficiency in biomass accumulation prior to grain filling for five crop species. Field Crops Res. 0: 51-64.

[4] Mitchell, P. L.; J. E. Sheehy and F. I. Woodward. 1998. Potential yields and the efficiency of radiation use in rice. IRRI Discussion Paper Series No. 32. International Rice Research Institute, Manila, Philippines.

[5] Sage, R. F. 2004. The evolution of C4 photosynthesis. New Phytologist. 161: 341-370.

[6] Nelson, T. And J. A. Langdale. 1992. Developmental genetics of C4 photosynthesis. Ann. Rev. Plant Physiol. Plant Mol. Biol. 43: 25-47.

[7] Brown, N.; K. Parsley and J. M. Hibberd. 2005. The future of C4 research maize, flaveria or cleome? Trends Plant Sci. 10: 215-221.

[8] Crookston, R. K. and D. N. Moss. 1974. Interveinal distance for carbohydrate transport in leaves of $\mathrm{C} 3$ and $\mathrm{C} 4$ grasses. Crop Sci. 14: 123-125.

[9] Hattersley, P. W. and L. Watson. 1975. Anatomical parameters forpredicting photo synthetic pathways of grass leaves: The 'maximum lateral cell count' and the 'maximum cells distant count'. Phytomorphology 25: 325-333.

[10] Dengler, N. G.; R. E.; Dengler, P. M.; Donnelly and P. W. Hattersley. 1994. Quantitative leaf anatomy of C3 and C4 grasses (Poaceae): Bundle sheath and mesophyll surface area relationships. Ann. Bot. (Lond.) 73: 241-255.

[11] Muhaidat, R.; R. F. Sage, and N. G. Dengler. 2007. Diversity of Kranz anatomy and biochemistry in $\mathrm{C} 4$ eudicots. Am. J. Bot. 94: 362-381.

[12] Crookston, R. K. and D. N. Moss. 1973. A variation of C4 leaf anatomy in Arundinella hirta (Gramineae). Plant Physiol. 52: $397-402$.

[13] Dengler, R. E. and N. G. Dengler. 1990. Leaf vascular architecture in the atypical NADP-malic enzyme grass Arundinella hirta. Can. J. Bot. 68: 1208-1221.

[14] Reger, B. J. and I. E. Yates. 1979. Distribution of photosynthetic enzymes between mesophyll, specialized parenchyma and bundle sheath cells of Arundinella hirta.
Plant Physiol. 63: 209-212.

[15] Dengler, N. G.; P. M. Donnelly and R. E. Dengler. 1996. Differentiation of bundle sheath, mesophyll, and distinctive cells in the $\mathrm{C} 4$ grass Arundinella hirta (Poaceae). Am. J. Bot. 83: 1391-1405.

[16] Wakayama, M.; J. Ohnishi and O. Ueno. 2006. Structure and enzyme expression in photosynthetic organs of the atypical C4 grass Arundinella hirta. Planta. 223: 1243-1255.

[17] McKown, A. D. and N. G. Dengler. 2009. Shifts in leaf vein density through accelerated vein formation in C4 Flaveria (Asteraceae). Ann. Bot. (Lond.) 104: 1085-1098.

[18] Yoshida, S.; D. A. Forno; J. H. Cock and K. A. Gomez. 1976. Laboratory manual for physiological studies of rice. Philippines: IRRI; 83.

[19] Zhao, K.; C. W. Tung; G. C. Eizenga; M. H. Wright; M. L. Ali; A. H. Price; G. J. Norton; M. R. Islam; A. Reynolds; J. Mezey; A. McClung; C. Bustamante and S. R. McCouch. 2011. Genome-wide association mapping reveals a rich genetic architecture of complex traits in Oryza sativa. Nature communications, 2: 467.

[20] Tung, C. W.; M. Wright; K. Zhao; A. Reynolds; J. Montgomery; G. Tanimoto; R. Barkovich; A. Pirani; G. Eizenga; A. McClung; C. Bustamante and S. McCouch. 2009. Design and performance of 44,100 SNP genotyping array for rice. Poster presented as part of the Plant and Animal Genomes XVIII conference, San Diego, California, 9-13 January 2010. Abstract published at "http://www.intlpag.org/", visited on 10 October 2012.

[21] Kang, H. M.; N. A. Zaitlen; C. M. Wade; A. Kirby; D. Heckerman; M. J. Daly and E. Eskin. 2008. Efficient control of population structure in model organism association mapping. Genetics, 178: 1709-1723.

[22] Yu, J. and E. S. Buckler. 2006. Genetic association mapping and genome organization of maize. Curr OpinBiotechnol, 17: 155-160.

[23] Alshugeairy, Z. 2013. Genetic, Phenomic and Molecular Analysis of Drought Avoidance and Recovery Traits in Rice for the Improvement of Plant Breeding. $\mathrm{PhD}$ thesis. Department of Plant and Soil Science. University of Aberdeen, UK.

[24] Sato, Y.; B. Antonio; N. Namiki; H. Takehisa; H. Minami; K. Kamatsuki; K. Sugimoto; Y. Shimizu; H. Hirochika and Y. Nagamura. 2011. RiceXPro: a platform for monitoring gene expression in japonica rice grown under natural field conditions. Nucleic Acids Research, 39: 1141-1148.

[25] Feldman, A. B.; E. H. Murchie; H. Leung; M. Baraoidan; R. Coe; S. Yu; S. Lo; W. P. Quick. 2014. Increasing Leaf Vein Density by Mutagenesis: Laying the Foundations for C4 Rice. PLoS ONE. 9 (4) e94947.

[26] Kanai, R. and G. E. Edwards. 1999. The Biochemistry of $\mathrm{C}_{4}$ Photosynthesis. In Sage RF, Monson RK. $\mathrm{C}_{4}$ Plant Biology. pp. 43-8.

[27] Christopher, J. T. and J. A. M. Holtum. 1996. Patterns of carbon partitioning in leaves of Crassulacean acid metabolism species during deacidification. Plant Physiol. 112 (1): 393399.

[28] Muthusamy S. k.; S. K. Singh; I. Singh; A. K. Singh; V. Chinnusamy and K. C. Bansal. 2013. Expression Analysis of C4 Photosynthetic Pathway Related Genes in Seven Rice Genotypes During Grain Filling Stage. Proc Indian natn Sci Acad 79 No. 1 pp. 91-98. 
[29] Kamadat, I.; S. Yamauchi; S. Youssefian and H. Sano. 1992. Transgenic tobacco plants expressing rgp 1, a gene encoding a ras-related GTP-binding protein from rice, show distinct morphological characteristics. The plant journal, 2 (5): 799807.

[30] Zhao H.; S. Lü; R. Li; T. Chen; H. Zhang; P. Cui; F. Ding; P. Liu; G. Wang; Y. Xia; M. P. Running and L. Xiong. 2015. The Arabidopsis gene DIG 6 encodes a large $60 \mathrm{~S}$ subunit nuclear export GTPase 1 that is involved in ribosome biogenesis and affects multiple auxin-regulated development processes. Journal of experimental botany, 66 (21): 6863-75.

[31] Abel, S. And A. Theologis. 1996. Early genes and auxin action. Plant Physiol 111: 9-17.

[32] Thimann, K. V. 1977. Hormone Action in the Whole Life of Plants. University of Massachusetts Press, Amherst, MA.

[33] Nagpal, P.; M. W. Loni; C. Y. Jeff.; S. Ami; T. Candace; E. Mark and W. R. Jason. 2000. AXR 2 Encodes a Member of the Aux/IAA Protein Family. Plant Physiology, Vol. 123, pp. 563573

[34] Dubos C.; R. Stracke; E. Grotewold; B. Weisshaar; C. Martin and L. Lepiniec. 2010. MYB transcription factors in Arabidopsis. Trends Plant Sci 15: 573-581.

[35] Allan A. C.; R. P. Hellens and W. A. Laing. 2008. MYB transcription factors that colour our fruit. Trends Plant Sci 13: 99-102.
[36] Ringli C. and B. Keller. 1998. Specific interaction of the tomato bZIP transcription factor

[37] VSF-1 with a non-palindromic DNA sequence that controls vascular gene expression. Plant Mol. Biol. 37: 977-988.

[38] Botha F. C. and J. G. C. Small. 1987. Comparison of the activities and some properties of pyrophosphate and ATP dependent fructose-6-phosphate 1-phosphotransferase of Phaseolus vulgaris seeds. Plant Physiol 83: 772-777.

[39] Persson B.; M. Krook; S. Atrian; R. Gonzalez-Duarte; J. Jeffery; D. Ghosh and H. Jornvall. 1995. Short-chain dehydrogenases/ reductases (SDR). Biochemistry 34 (18): 6003-6013.

[40] Oppermann, U.; C. Filling; M. Hult; N. Shafqat; X. Wu; M. Lindh; J. Shafqat; E. Nordling; Y. Kallberg and B. Persson. 2003. Short-chain dehydrogenases/reductases (SDR): Chem. Biol. Interact. 247-253.

[41] Xie, X.; Y. Wang; L. Williamson; G. H. Holroyd; C. Tagliavia; E. Murchie; J. Theobald; M. R. Knight; W. J. Davies; H. M. Leyser and A. M. Hetherington. 2006. The identification of genes involved in the stomatal response to reduced atmospheric relative humidity. Curr. Biol. 9; 16 (9): 882-887. 